\title{
Prevalensi Dengue pada Mahasiswa Universitas Surabaya
}

\author{
Dina Chamidah* \\ Fakultas Bahasa dan Sains Universitas Wijaya Kusuma Surabaya \\ *e-mail: dina.chamidah@yahoo.co.id
}

\begin{abstract}
Abstrak
Di Indonesia demam berdarah masih sering terjadi. Ini telah membuat banyak orang bermasalah di Indonesia termasuk Surabaya, Jawa Timur. Tanda-tanda klinis demam berdarah dimulai dari penyakit ringan hingga sindrom kejut yang mengancam jiwa. Sehingga dibutuhkan suatu pengembangan pengobatan untuk menanggulangi demam berdarah. Tujuan penelitian ini adalah untuk melihat prevalensi demam berdarah pada mahasiswa. Prevalensi demam berdarah di Universitas Surabaya dihitung $17 \%$, saat kami mendekati 81 orang di antara mereka 14 terinfeksi demam berdarah dengue. Ada 42 (65\%) orang yang menderita sakit kepala, $19(29 \%)$ layuh sendi, $26(40 \%)$ nyeri otot dan $16(25 \%)$ menderita sakit perut, dan dari 64 orang antara kelompok usia 18-23 tahun. Data yang diperoleh sangat membantu dalam menentukan pendekatan terapeutik terhadap infeksi yang muncul. Selanjutnya hubungan faktor demografi seperti umur, gender, status sosial ekonomi dengan transmisi virus dengue juga sedang dipertimbangkan.
\end{abstract}

Kata kunci: Demam berdarah, Aedes aegypti, faktor demografi.

\section{Prevalence of Dengue at Universitas Surabaya's Students}

\begin{abstract}
In Indonesia, dengue fever is still common. This has caused many troubled people in Indonesia including Surabaya, East Java. Clinical signs of dengue start from mild illness to life-threatening shock syndrome. So it takes a development of a treatment to combat dengue fever. The purpose of this study is to see the prevalence of dengue fever in students. The prevalence of dengue fever at the University of Surabaya accounted for $17 \%$, as we approached 81 people among them 14 were infected with dengue hemorrhagic fever. There were $42(65 \%)$ people suffering from headaches, $19(29 \%)$ joints, $26(40 \%)$ muscle pain and 16 (25\%) had abdominal pain, and from 64 among the 18-23 age group. The data obtained is helpful in determining the therapeutic approach to infections that appear. Furthermore, demographic factors such as age, gender, socioeconomic status with dengue virus transmission are also being considered.
\end{abstract}

Keywords: Dengue fever, Aedes aegypti, demographic factor.

\section{PENDAHULUAN}

Penyakit Hemorrhagic Fever (DHF) atau dikenal dengan DBD adalah penyakit yang penyebab utamanya adalah virus dengue yang cara penularannya melalui gigitan nyamuk Aedes aegyti dan Aedes albbopictus. Pada saat musim hujan, banyak genangangenangan pada gorong-gorong yang tersumbat yang sangat potensial sebagai tempat berkembangbiak nyamuk yang menyebabkan peningkatan penyebaran penyakit demam berdarah. perkembangan angka reproduksi nyamuk bisa ditekan secara alami atau kimiawi. Namun diharapkan cara alami yang digunakan sehingga kesehatan manusia terjaga. Manusia pada hakekatnya sudah mengetahui dan mengenal nyamuk, tetapi nyamuk sering mengganggu ketenangan manusia, sehingga dengan berbagai cara, manusia berusaha membinasakan dan memusnahkan nyamuk.

Di dunia, pada tahun 2008 sampai 2010 terjadi peningkatan dari 1,2 juta kasus menjadi 2,2 juta kasus, sehingga menyebabkan banyak nyawa yang hilang. DBD dapat menyerang semua kelompok umur. Penyakit ini berhubungan kebiasaan masyarakat dan keadaan lingkungan sekitar. 
ISSN 1978-2071 (Print); ISSN 2580-5967 (Online)

Jurnal IImiah Kedokteran Wijaya Kusuma 6(1) : 45-48

Gambar 1. Grafik Bulanan Kasus DBD Kota Surabaya Tahun 2011-2015 (1).

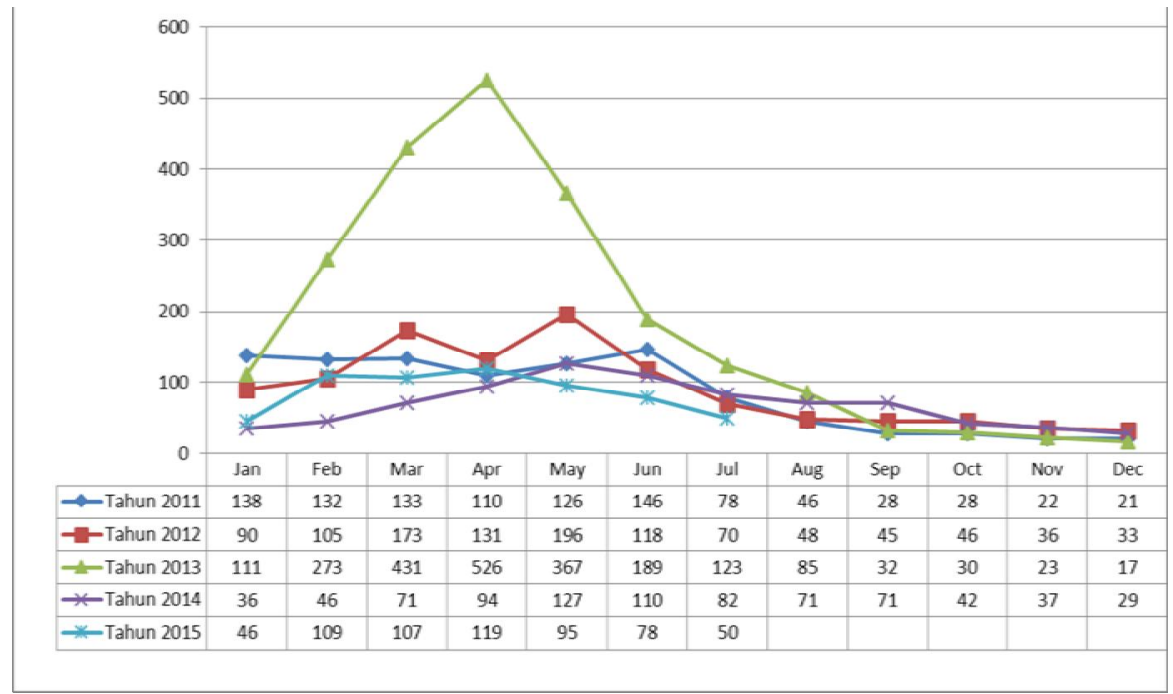

Pada Gambar 1 menunjukkan bahwa grafik kasus DBD tahun 2015 di Kota Surabaya naik turun setiap bulannya. Peningkatan jumlah bulan Maret. Penurunan jumlah kasus DBD bulan Maret sampai bulan Juli 2015. kasus DBD terjadi pada bulan Januari sampai

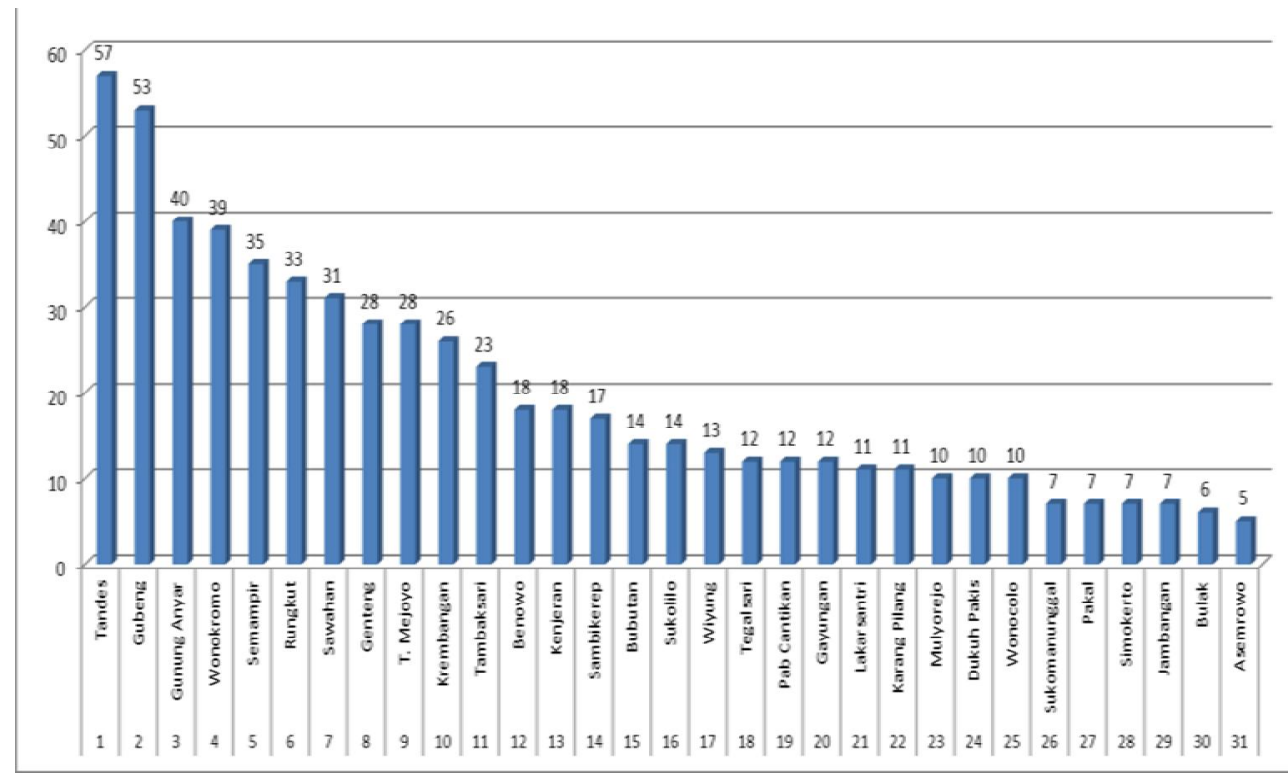

Gambar 2. Sebaran Kasus DBD Berdasarkan Kecamatan Kota Surabaya Bulan Januari-Agustus 2015 (2)

Kementerian Kesehatan Republik Indonesia (2012), mengutarakan kejadian DBD berdasarkan umur dari tahun 1993-2009. Dari tahun 1993-1998 kasus terbesar DBD adalah umur $<15$ tahun. Tahun 1999-2009 lebih banyak pada kelompok umur > 15 tahun. Berdasarkan jenis kelamin, tahun 2008 menunjukkan prosentase yang hampir sama antara penderita laki-laki dan perempuan.
Jumlah penderita laki-laki sebanyak 10.463 orang $(53,78 \%)$ dan perempuan sejumlah 8.991 orang $(46,23 \%)$. Dapat di buat kesimpulan bahwa gender atau jenis kelamin tidak mempengaruhi naik turunnya kejadian DBD (3).

DBD terjadi saat musim hujan, vektor nyamuk DBD meningkat populasinya. Sanitasi yang kurang lancar menyebabkan sarang nyamuk semakin bertambah dan berkontribusi 
terhadap peningkatan insiden DBD. Saat musim kemarau Aedes aegypti bersarang pada tempat penampungan yang terisi air dan jarang dikuras. M isalnya bak kamar mandi, tempayan dan drum. DBD lebih banyak kita temukan di perkotaan yang memiliki populasi penduduk yang padat, sehingga cara penularannya mudah dan cepat.

Ada tiga cara untuk mengatasi infeksi dengue, yaitu menggunakan tindakan pencegahan. Kita bisa mencegah diri dengan menghindari kontak dengan nyamuk yang terinfeksi. Gigitan nyamuk A. aegypti pada siang hari dan kontaknya bisa dihindari dengan berbagai cara. Pengelolaan limbah yang tepat dan penyulingan penyimpanan air, membersihkan semua sumber air, menggunakan pestisida, repellents serangga, mengenakan gaun lengan panjang. Yang kedua adalah vaksinasi dan yang ketiga adalah terapi obat namun belum ada obat antiviral yang dapat diakses (4).

Berbagai cara pengendalian DBD dilakukan misalnya sosialisasi kesehatan tentang pemberantasan sarang nyamuk, serta kerja sama sampai dengan tingkat desa/kelurahan, misalnya perkantoran, perumahan, perkampungan, pedesaan, lingkungan sekolah dan akademisi untuk pemberantasan sarang nyamuk. Permasalahan pokok adalah belum maksimalnya dalam pemberantasan sarang nyamuk DBD. Berdasarkan latar belakang diatas maka sangat diperlukannya sosialisasi di lingkungan masyarakat, khususnya lingkungan sekolah dan akademisi, sehingga peneliti mencoba melakukan penelitian untuk mengetahui dan menganalisis tentang prevalensi dengue pada mahasiswa yang berada dalam lingkungan kampus khususnya Universitas Surabaya. Tujuan yang akan dicapai dalam penelitian adalah (a) untuk mengetahui total prevalensi demam berdarah pada mahasiswa; (b) untuk mengetahui prevalensi demam berdarah berbasis jender (jenis kelamin); (c) untuk mengetahui bagaimanakah prevalensi demam berdarah berdasarkan usia.

Gejala DBD adalah demam, sakit kepala berat, layuh otot (myalgias dan arthralgias) dan ruam. Ruam merah terang muncul pertama kali pada bagian bawah, badan dan lalu menyebar hampir seluruh tubuh. Sakit perut sesekali muncul disertai rasa mual, muntahmuntah/ diare.

\section{BAHAN DAN METODE}

Penelitian dilakukan di Universitas Surabaya. Di universitas ini mahasiswanya berasal dari berbagai suku dan daerah yang ada di Indonesia. Status sosial ekonomi mereka berbeda-beda sehingga kedua jenis kelamin tersebut diambil dalam studi prevalensi demam berdarah pada mahasiswa. Subyek meliputi mahasiswa Program Studi Magister IImu Kenotaritan dan IImu Hukum, mahasiswa tinggal di rumah pribadi, rumah kos, rumah kontrakan dan apartemen. Kuesioner dibuat untuk mengumpulkan semua informasi. Sebanyak 81 individu di antaranya laki-laki dan perempuan didekati untuk mengetahui prevalensi demam berdarah pada bulan Oktober 2016 sampai Januari 2017 di kalangan mahasiswa. Data demografi, semua pasien dikumpulkan, yang meliputi jenis kelamin, usia, riwayat penyakit, pekerjaan, tingkat pendidikan, aktivitas kerja sehari-hari (tidak banyak duduk atau tidak menetap), dan perilaku kesehatan dan lain-lain.

\section{HASIL}

\section{Prevalensi Demam Berdarah}

Pada Gambar 3. menunjukkan prevalensi demam berdarah berdasarkan jenis kelamin, usia dan prevalensi keseluruhan telah dihitung dalam penelitian ini. Didapatkan hasil bahwa dari 81 orang, 14 (17\%) menderita demam berdarah dan 67 (83\%) ditemukan normal.

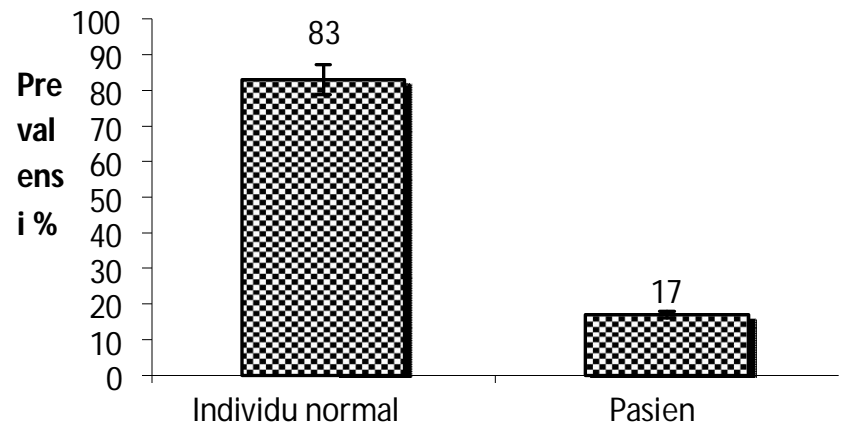

Gambar 3. Prevalensi total Demam Berdarah pada mahasiswa

Pada Gambar 4. menunjukkan prevalensi berbasis gender (jenis kelamin), diamati bahwa dari 67 laki-laki 28 (35\%) normal, sementara 5 (19\%) menderita infeksi. Sementara dari 14 perempuan 39 (48\%) normal dan 9 (11\%) adalah pasien. 


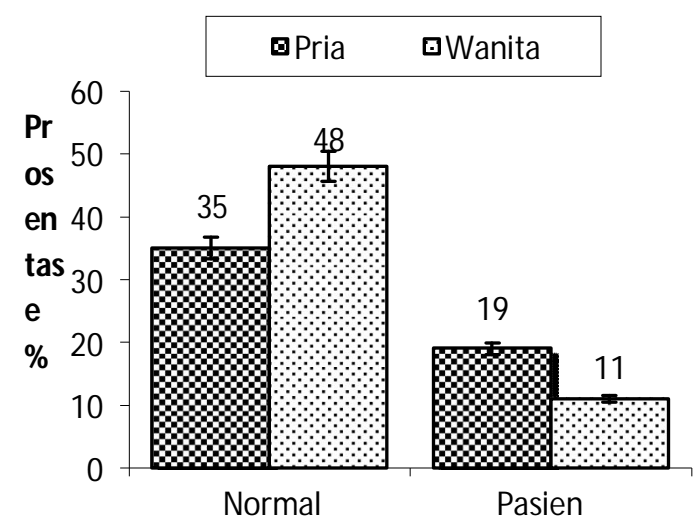

Gambar 4. Prevalensi Dengue berbasis gender (Jenis Kelamin)

Pada Gambar 5. menunjukkan prevalensi berbasis usia bahwa dari 81 responden, ada 64 (79\%) orang yang menderita demam berdarah, di antara kelompok usia 18-23, 15 (19\%) orang di antara kelompok usia 24-29, 1 (100\%) orang di antara kelompok umur 30-36 tahun dan tidak ada pasien demam berdarah yang ditemukan di antara kelompok usia 37-41 tahun.

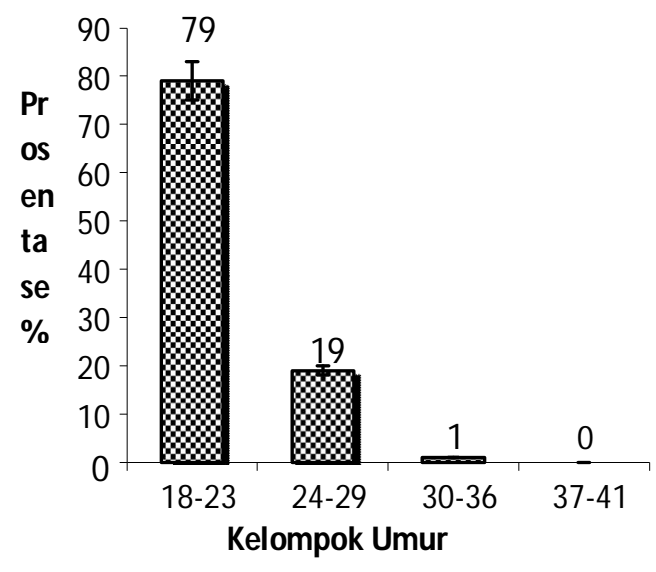

Gambar 5. Prevalensi demam berdarah berdasarkan usia

Pada Tabel 1. menunjukkan adanya berbagai faktor terjadinya hubungan antara demam berdarah dengan gejala penyakit yang diderita, dari orang-orang dengan kelompok usia yang berbeda. Di antara kelompok usia 1823 tahun, dari 64 orang, ada $42(65 \%)$ orang yang menderita sakit kepala, 19 (29\%) layuh sendi, 26 (40\%) nyeri otot dan 16 (25\%) menderita sakit perut. Di antara kelompok usia 24-29 tahun, dari 15 orang, ada 6 (40\%) orang yang menderita sakit kepala, $6(40 \%)$ layuh sendi, 5 (33\%) nyeri otot dan 5 (33\%) menderita sakit perut. Di antara kelompok usia 30-36 tahun, satu-satunya 1 responden menderita sakit kepala, layuh sendi, nyeri otot dan sakit perut. Di antara kelompok usia 37-41 tahun tidak ada orang yang menderita salah satu faktor.

Tabel 1. Faktor yang terkait dengan demam berdarah pada kelompok usia yang berbeda

\begin{tabular}{|c|c|c|c|c|}
\hline \multicolumn{5}{|c|}{ Usia Tanda dan Gejala } \\
\hline & $\begin{array}{c}\text { Sakit } \\
\text { Kepala }\end{array}$ & $\begin{array}{l}\text { Layuh } \\
\text { Sendi }\end{array}$ & $\begin{array}{l}\text { Nyeri } \\
\text { Otot }\end{array}$ & $\begin{array}{l}\text { Sakit } \\
\text { Perut }\end{array}$ \\
\hline $18-23$ & $42(65 \%)$ & $19(29 \%)$ & $26(40 \%)$ & $16(25 \%)$ \\
\hline $24-29$ & $6(40 \%)$ & $6(40 \%)$ & $5(33 \%)$ & $5(33 \%)$ \\
\hline $30-36$ & $1(100)$ & $1(100)$ & $1(100)$ & $1(100)$ \\
\hline $37-41$ & $0(0 \%)$ & $0(0 \%)$ & $0(0 \%)$ & $0(0 \%)$ \\
\hline
\end{tabular}

\section{PEM BAHASAN}

Menurut hasil penelitian, prevalensi demam berdarah di Universitas Surabaya dihitung $17 \%$ dari 81 orang, di antaranya 14 terinfeksi demam berdarah dengue. Data yang dievaluasi berdasarkan jenis kelamin, ada sedikit perbedaan dalam prevalensi demam berdarah karena berbagai aktivitas rutin individu pria dan wanita dari populasi juga berbeda. Wanita memiliki frekuensi penyakit yang lebih rendah dibandingkan dengan pria karena pria memiliki aktivitas di luar ruangan lebih besar yang dapat membiarkan vektor tersebut mengaksesnya lebih banyak daripada wanita yang tetap berada di rumah selama aktivitas vektor virus dengue tinggi. Data pada tingkat usia, didapatkan hasil bahwa orangorang dengan usia 18-23 dan 24-29 terinfeksi lebih banyak dibandingkan dengan orang-orang dari kelompok usia di atas 29 tahun, dimungkinkan disebabkan oleh beberapa alasan misalnya orang usia muda banyak yang menghabiskan waktu mereka dan beraktifitas di luar ruangan serta bermain di taman-taman bermain dimana ada banyak vektor dan vektor virus dengue dengan mudah mengaksesnya dan mengirimkan patogen kepada mereka, sementara orang-orang berusia lanjut seperti di atas 30 tidak banyak terlibat dalam kegiatan di luar ruangan. Di antara faktor yang terkait dengan demam berdarah yaitu timbulnya gejala penyakit sakit kepala, layuh sendi, nyeri 
ISSN 1978-2071 (Print); ISSN 2580-5967 (Online)

Jurnal IImiah Kedokteran Wijaya Kusuma 6(1) : 45-48

otot dan sakit perut. Ketidak hati-hatian dan kecerobohan dalam segala hal juga bisa menjadi faktor, karena di masa muda orang tidak peduli dengan aktivitas mereka sementara orang yang berusia lebih tua memiliki kesadaran yang baik dan mereka peduli terhadap peringatan kesehatan.

\section{KESIM PULAN}

Dapat disimpulkan bahwa pentingnya dimulainya secara konsisten sosialisasi untuk menumbuhkan kesadaran masyarakat akan demam berdarah. Perlunya pelayanan kesehatan dari dokter dan petugas kesehatan yang memberikan pelayanan yang menyenangkan, memberikan perawatan simpatik yang terbaik kepada masyarakat, dan juga mengajarkan masyarakat tentang penyebaran demam berdarah dan pengendalian vektor.

\section{DAFTAR PUSTAKA}

1. Dinas Kesehatan Kota Surabaya, 2015. Profil Kesehatan Kota Surabaya. Surabaya. Dinas Kesehatan Kota Surabaya.

2. Kementrian Kesehatan RI, 2015. Profil Kesehatan Rl. Jakarta: Kementrian Kesehatan RI.

3. Kementrian Kesehatan RI, 2012. Modul Pengendalian Demam Berdarah Dengue. Jakarta: Kementrian Kesehatan RI.

4. Selisko B, Guillemot JC, Alvarez K, Canard B, 2006. Opportunities in the development of ANTI-dengue drugs. Geneva. 